\title{
Investment fund selection techniques from the perspective of Brazilian pension funds
}

\author{
Jéssica Santos de Paula ${ }^{1}$ \\ (D) https://orcid.org/0000-0002-0140-5881 \\ Email: santosdepaula.jessica@gmail.com
}

Robert Aldo Iquiapaza ${ }^{2}$

(iD) https://orcid.org/0000-0003-1657-2823

Email: rbali@ufmg.br

\begin{abstract}
${ }^{1}$ Rodarte Nogueira - Consultoria em estatística e atuária, Belo Horizonte, MG, Brazil
${ }^{2}$ Universidade Federal de Minas Gerais, Faculdade de Ciências Econômicas, Centro de Pós-Graduação e Pesquisas em Administração, Belo Horizonte, MG, Brazil
\end{abstract}

Received on 03.19.2020 - Desk acceptance on 05.08.2020 - $2^{\text {nd }}$ version approved on 06.16.2021

Editor-in-Chief: Fábio Frezatti

Associate Editor: Luís Eduardo Afonso

\begin{abstract}
The aim of this article was to evaluate the effectiveness of investment fund selection techniques from the perspective of Brazilian pension funds. Asset liability management (ALM) and liability driven investment (LDI) strategies are usually adopted to guide pension fund managers in relation to strategic allocation in asset classes that should compose their investment portfolios and to the liquidity needed in each period, but not specifying in which assets to allocate resources from among the infinity of assets available in the financial market. This article contributes to tactical management in the fixed income and stock segments outsourced via funds and demonstrates that adopting simple indicators can increase investment performance. The article broadens the knowledge on pension fund investment decisions and creates confidence in the adoption of the Sharpe ratio as a technique for choosing investment funds. We analyzed the returns obtained by hypothetical portfolios built using the following techniques: (i) the Sharpe ratio; (ii) the alpha of a multifactor model; (iii) data envelopment analysis (DEA) efficiency; and (iv) the different combinations of these techniques. We considered information on 369 funds from 2013 to 2018, adopting 12 temporal windows for choosing and re-evaluating the portfolios. The returns obtained were compared with the mean actuarial goal of the benefits plans administered by the pension funds, by means of the unplanned divergence (UD). When outsourcing pension fund investments in fixed income and stock investment funds it was verified that the Sharpe ratio contributes significantly to pension fund performance, compared with other indicators and techniques or a combination of them.
\end{abstract}

Keywords: pension funds, performance analysis, investment funds, data envelopment analysis, unplanned divergence. 


\section{INTRODUCTION}

An investment fund is a type of financial application that combines the resources of various investors, with the aim of obtaining financial gains based on collective investments in an asset portfolio. According to data from the Brazilian Association of Financial and Capital Market Entities (ANBIMA, 2019), the investment fund industry reached more than $\mathrm{R} \$ 8.5$ trillion in net assets under management, $64 \%$ of which was in investment funds and $36 \%$ was in investment funds with shares, or "quotas," in investment funds. The segment totaled 19.1 thousand funds with 20.9 million quota holders (ANBIMA, 2019).

Within the context of pension funds, which account for R\$ 949.9 billion in the financial market, $67 \%$ of the resources are invested through investment funds, this therefore being the predominant investment modality in this area, according to the Brazilian Association of Closed Complementary Pension Entities (Abrapp, 2019).

Historically, the representativeness of investment funds in the pension fund portfolio has become increasingly greater over the years, as well as assets classified in the fixed income segment. This has occurred because, with the increase in the remuneration of government bonds in the period from 2010 to 2014, pension fund investment in these assets intensified, leading to $73 \%$ of their consolidated portfolio being predominantly allocated in the fixed income segment, $54.3 \%$ of which was through investment funds (Abrapp, 2019).

Despite this conservative portfolio being observed among pension funds worldwide, as noted by the Organisation for Economic Co-operation and Development (OECD, 2018), a fall in the remuneration of these assets may compromise the capacity to pay benefits in pension plans. This occurs because low remuneration of government bonds may reduce the expected return of benefits plans, meaning that lower discount rates are assumed to establish the monetary value of their future responsibilities.

However, given the potential of pension funds to drive the country's economy and the context of structural and conjunctural reforms, including in the pension system, the importance of managing their guarantee resources is underlined. This should be guided by strategic allocation, taking advantage of market opportunities, thus guaranteeing not only higher return than the actuarial goal, but also financial slack that provides greater security to the plan's liabilities (Bertucci et al., 2006).

One of the most recent problems of pension funds is the low remuneration on the assets that compose their investment portfolios, which may compromise their capacity to pay benefits and/or increase their risk of insolvency (Guiotti et al., 2020). This difficulty can be faced in different stages of the investment decision of these institutions. In a first stage, strategic allocation can be made in the different asset and risk classes allowed by the rules and policies of these institutions. For example, active and passive management techniques can be adopted, such as asset liability management (ALM) and liability driven investment (LDI) (Bogentoft et al., 2001; Hibiki, 2006; Mitra \& Medova, 2010; Oliveira et al., 2017, 2018). After this strategic directioning regarding allocation into different asset types, it is necessary to specify the specific assets for allocating resources from among the infinity of alternatives in the fixed income and stock markets available in the financial market. This article contributes, in this stage of the investment decision of pension funds, by comparing the performance of some allocation techniques proposed in the literature and it evaluates the performance of these in the specific context of pension funds, considering a sample of investment funds meant for qualified and professionals investors that follow the guidelines of CMN Resolution n. 4,661/2018, issued by the Central Bank of Brazil, which is specific to pension funds.

The study of investment selection techniques in the area of pension funds remains scarcely explored in the literature. Most of the studies focus on analyzing the profile of the investments of benefits plans according to the type of management (public or private), characteristics of their body of participants, and their maturity level [Andonov et al. (2017), Blake et al. (2013, 2017), Bradley et al. (2016), Dujim and Steins Bisschop (2018), Edelen et al. (2016), Lakonishok et al. (1991), Novy-Marx and Rauh (2011), Rauh (2008), among others].

Active and passive management strategies, such as ALM, LDI, or goal-based investment (GBI), which aim to increase the probability of achieving goals (Nevins, 2004), guide pension fund managers regarding the classes and characteristics of the assets that should compose their portfolios and regarding the liquidity needed in each period, as well as the approach toward the risk of not achieving the defined goal, also considering the profile and characteristics of the clients (Mitra \& Medova, 2010; Oliveira et al., 2017, 2018). However, they do not specify in which specific assets to allocate resources from among those available in the financial market, summarizing in a few assets the infinity of financial instruments, such as the 
studies of Correia et al. (2018), Saad and Ribeiro (2004), and Silva et al. (2015), which perform the optimization of Brazilian pension fund portfolios by applying ALM, considering asset classes, primarily fixed income in the first two, including fixed income and stock (Correia et al., 2018) and with the addition of structured assets, foreign assets, real estate, and operations with participants (Silva et al., 2015).

Therefore, the present article is warranted as it analyzes investment fund selection techniques, in a subsequent stage to in the ALM, LDI, or GBI studies, from the perspective of pension fund investments. Only those that follow the rules specified in the pension fund legislation are therefore considered. Thus, the application of resources in such funds will not result in non-compliance with the current rules and can provide a broader analysis of the investment options available in the market.

Therefore, the aim of this article is to evaluate investment fund selection techniques from the perspective of Brazilian pension funds. The specific objectives include: (i) analyzing the proposals for choosing investment funds in the fixed income and stock segments, based on performance indicators (Sharpe ratio and factor model alpha) and efficiency [calculated using data envelopment analysis (DEA)] and combinations of them, attributing scores to the funds and comparing their results; and (ii) analyzing the effectiveness of the techniques evaluated by comparing the returns of the investment funds chosen with the actuarial goal of the benefits plans by means of the unplanned divergence (UD).

The article is structured in five sections. The first presents the contextualization and the aims of the research. The second presents the theoretical framework of the study. The third presents the analysis methodology adopted. The fourth presents the results found and the fifth presents the concluding remarks.

\section{THEORETICAL FRAMEWORK}

\subsection{Investment Fund Selection Techniques}

Various factors can be observed in investment decisions, such as the desired level of return, the investor's appetite for risk, and the purpose of the investment. Pension funds, which have a long-term commitment to their participants, should compose their portfolios of investments so as to guarantee solvency and liquidity up to the expected date of payment of their last benefit and, for that reason, they end up composing their portfolios in a conservative way, investing directly in government bonds or through collective investments, such as investment funds (OECD, 2018).

The investment strategies of pension funds follow investment policies that must be approved by the respective deliberative councils. This investment policy determines the assets that can be invested in, observing the modalities, the segments, the limits, and the other criteria and requirements established in the legislation (Gutierrez et al., 2019). Ibbotson and Kaplan (2000) verify that the asset allocation policy explains approximately $90 \%$ of the variability of returns of a mutual or pension fund over time and $40 \%$ of the variation in returns observed among funds.

However, the policy is not the only factor responsible for fund performance. The asset manager's knowledge and experience are also relevant. Given the vast number of financial assets available in the financial market, investment decisions can be influenced by both technical and political factors and, in the case of the former, it is important to adopt the appropriate tools for this purpose.

In the literature, there is a wide variety of tools that can be used to evaluate investment performance, guaranteeing some basis for choosing a financial application. Simple techniques, which enable an evaluation of the return on an investment according to the level of risk incurred, are widely used, such as the Sharpe ratio and Jensen's alpha. On the other hand, more complex techniques enable an infinity of factors to be considered when evaluating an investment, such as DEA, which is widespread in financial analyses.

Varga (2001) evaluated the application of different performance indicators for choosing Brazilian equity funds in the period from 1997 to 1999. The author's conclusion was that the appropriate indicator depends on the importance of the portfolio to the investor: (i) when there are no risk investments and their aim is to build a portfolio to be their only investment with risk, the Sharpe ratio is the most appropriate indicator; (ii) when there is a market portfolio and their aim is to add an investment with risk, the appraisal ratio (AR) is the most appropriate indicator; and (iii) when the aim is to evaluate the performance of the existing portfolio to reallocate it and increase its performance, the most appropriate 
indicator is systemic risk. However, when comparing the funds that excel with the different measures, the results are practically the same.

A similar result was observed by Eling (2008), when analyzing investment funds in seven asset classes in the period from 1996 to 2005 . The author's hypothesis was that the Sharpe ratio would not be an appropriate performance indicator when the series of returns does not present a normal distribution. However, the author verified that the choice of performance measure does not significantly influence the classification of investment funds and that the Sharpe ratio can be considered a better measure than the rest as it is better known and understood, as well as being consistent with the desired maximization of utility.

On the other hand, Ornelas et al. (2012) verified that the performance measures applied to investment funds have similar classifications only when the numerator is the same in their formula, in this case the excess return in relation to the risk-free rate. However, when other performance measures are adopted, the results can be significantly different. Ornelas et al. (2012) also emphasize that the adoption of various performance measures would have a positive impact on the choice of investment.

Zakamouline (2010) obtained similar results by evaluating hedge funds, also verifying that the high correlation in the classification of funds obtained with the Sharpe ratio and with other alternative measures is explained by the period adopted to evaluate the performance of the sample of returns used. Therefore, unlike the method adopted by Eling (2008), when the series are evaluated in periods other than monthly and when series of return with a more distant distribution from normal are adopted, it is possible to obtain significantly different classifications.

Bragança and Pessoa (2017) analyzed the performance of Brazilian multi-market investment funds based on the application of different asset pricing models, such as the Fama and French (1993) model, the Carhart (1997) model, and multifactor models that sometimes incorporate factors related to the stock segment and sometimes include factors related to the fixed income segment. The authors verified similar results for the models, except when fixed income factors were incorporated, which increased the explanatory power of the models.

From another perspective, Fonseca et al. (2018) compared the performance of investment funds by adopting a parametric technique [alpha from the model proposed by Carhart (1997)] and another non-parametric one (DEA). The authors verified that the alphas from the Carhart model have a high correlation with the returns of the funds, which was not observed for the scores obtained using DEA, highlighting that the choice of performance evaluation method is an important stage in the process of choosing investments.

Rubio et al. (2018) incorporated the efficiency scores measured through DEA into the asset pricing model proposed by Carhart (1997) to evaluate investment fund performance. The authors verified that the efficiency scores have explanatory power regarding fund returns, reducing the estimation error of the model.

Other studies have been developed not specifically to compare the results of different performance measures, but to effectively evaluate investment fund performance: that of Fonseca et al. (2007), who evaluated the performance of fixed income and stock funds, adopting the Sharpe ratio and Sortino ratio; and those of Ayadi and Kryzanowsky (2011) and Ayadi et al. (2018), who evaluated the performance of Canadian fixed income funds based on a multifactor model that incorporates indicators from the fixed income segment and other factors.

There are also studies that have evaluated the performance of different types of funds by adopting DEA, such as that of Macedo et al. (2010), who analyzed fixed income funds, those of Bisso et al. (2016) and Ceretta and Costa (2001), who analyzed stock funds, and that of Melo and Macedo (2013), who analyzed multimarket funds. Silva et al. (2020) also evaluated the portfolio turnover and performance of equity investment funds in Brazil, identifying a positive relationship between them.

Within the context of pension funds, Oliveira and Pinheiro (2012) analyzed the performance of equities in the Brazilian market using the CCR model (an abbreviation of Charnes, Cooper, and Rhodes (1978), the surnames of its authors) of DEA. Based on the application of that technique in the period from 2001 to 2007, Oliveira and Pinheiro (2012) obtained a three times higher return than would be obtained if the passive investment technique were adopted.

\subsection{Investment Performance Indicators}

Investment performance indicators can be measured in different ways, indicating to the investor the return on an asset for a certain level of risk exposure. This, in turn, can be measured in terms of the market or the asset itself, also making it a performance measure, in that the lower the risk, the better, from the perspective of pension funds. Table 1 presents some performance indicators adopted in this study to evaluate the investment fund selection techniques proposed. 
Table 1

Performance indicators

\begin{tabular}{|c|c|c|}
\hline Indicator & Description & Formula \\
\hline $\begin{array}{l}\text { Sharpe ratio } \\
\text { (Sharpe, 1966) }\end{array}$ & $\begin{array}{l}\text { Expected return }\left(\bar{R}_{\mathrm{i}}\right) \text { beyond the risk-free asset }\left(\bar{R}_{\mathrm{f}}\right) \\
\text { divided by the risk that this runs }\left(\sigma_{\mathrm{i}}\right) \text {. }\end{array}$ & $\mathrm{SR}=\frac{\overline{\mathrm{R}}_{\mathrm{i}}-\overline{\mathrm{R}}_{\mathrm{f}}}{\sigma_{\mathrm{i}}}$ \\
\hline $\begin{array}{l}\text { Jensen's alpha } \\
\text { (Jensen, 1968) }\end{array}$ & $\begin{array}{l}\text { Excess return in relation to the risk-free asset }\left(\bar{R}_{\mathrm{f}}\right) \\
\text { and to the gain according to the risk incurred }\left(\beta_{i}\right) \text { in } \\
\text { relation to the market portfolio }\left(\bar{R}_{m}\right) \text {. }\end{array}$ & $\alpha_{i}=\bar{R}_{i}-\bar{R}_{f}-\beta_{i}\left(\bar{R}_{m}-\bar{R}_{f}\right)$ \\
\hline $\begin{array}{l}\text { M² } \\
\text { (Modigliani \& Modigliani, 1997) }\end{array}$ & $\begin{array}{l}\text { Excess return of the fund when compared to the } \\
\text { return on the market portfolio }\left(\bar{R}_{\mathrm{m}}\right) \text {, after adjusting } \\
\text { the fund's return }\left(\bar{R}_{\mathrm{i}}\right) \text { to the market risk }\left(\sigma_{\mathrm{m}}\right) \text {, as if } \\
\text { both had the same volatility. }\end{array}$ & $\begin{array}{c}M^{2}=\bar{R}_{c}-\bar{R}_{m^{\prime}} \text { where } \\
\bar{R}_{c}=\frac{\sigma_{m}}{\sigma_{i}} \times \bar{R}_{i}+\left(1-\frac{\sigma_{m}}{\sigma_{i}}\right) \times \bar{R}_{f}\end{array}$ \\
\hline $\begin{array}{l}\text { Sortino ratio } \\
\text { (Sortino \& Van Der Meer, 1991) }\end{array}$ & $\begin{array}{l}\text { Similar to the Sharpe ratio, differing only in the risk } \\
\text { measure, as it uses the volatility occurring only in } \\
\text { the returns below a certain reference value. }\end{array}$ & $\theta=\frac{\overline{\mathrm{R}}_{\mathrm{i}}-\overline{\mathrm{R}}_{\mathrm{f}}}{\sqrt{\frac{1}{N} \sum_{i=1}^{N}\left[\operatorname{Min}\left(0 ; R_{i}-\overline{\mathrm{R}}_{\mathrm{f}}\right)\right]^{2}}}$ \\
\hline $\begin{array}{l}\text { AR (appraisal ratio) } \\
\text { (Treynor \& Black, 1973) }\end{array}$ & $\begin{array}{l}\text { Value added to the portfolio due to assuming a } \\
\text { different risk from the market risk. }\end{array}$ & $\begin{array}{l}\qquad \mathrm{AR}=\frac{\alpha_{\mathrm{i}}}{\sigma_{\varepsilon}} \\
\text { where } \alpha_{\mathrm{i}} \text { is the Jensen's alpha } \\
\text { and } \sigma_{\varepsilon} \text { is the non-systematic risk }\end{array}$ \\
\hline Systemic beta & $\begin{array}{l}\text { Measure of sensitivity of the fund's return }\left(\mathrm{R}_{\mathrm{i}}\right) \text { in } \\
\text { relation to the return of a market index }\left(\mathrm{R}_{\mathrm{m}}\right) \text {. }\end{array}$ & $\beta_{\mathrm{i}}=\frac{\operatorname{Cov}\left(\mathrm{R}_{\mathrm{i}}, \mathrm{R}_{\mathrm{m}}\right)}{\operatorname{Var}\left(\mathrm{R}_{\mathrm{m}}\right)}$ \\
\hline Parametric VaR & $\begin{array}{l}\text { Maximum potential variation measure of the } \\
\text { value of a portfolio with a given probability in a } \\
\text { predefined horizon. }\end{array}$ & $\begin{array}{c}\qquad \mathrm{VaR}=\mathrm{z}_{(1-\alpha)} * \sigma_{\mathrm{i}} \\
\text { where } o(1-\alpha) \text { is a quantile of the standardized } \\
\text { normal distribution }(N \sim(0,1)), 0<\alpha<1 \text { and } \sigma_{i} \text { is } \\
\text { the fund's volatility }\end{array}$ \\
\hline Historical VaR & $\begin{array}{l}\text { Similar to the parametric VaR, considering the } \\
\text { histogram of expected returns. }\end{array}$ & $\begin{array}{l}\qquad \operatorname{Va}_{a}(\mathrm{X})=\min \{z \mid F x(z) \geq 1-\alpha\} \\
1-\alpha \text { is the confidence level, and } \operatorname{Va}_{a}(X) \text { is the } \\
\text { percentile that results in the highest expected loss }\end{array}$ \\
\hline Conditional VaR & $\begin{array}{l}\text { Expected loss of an investment, given that this } \\
\text { exceeds the VaR. }\end{array}$ & $\begin{array}{l}C \mathrm{CVaR}=\mathrm{E}(\mathrm{X} \mid \mathrm{X}>\mathrm{VaR}) \text {, } \\
\text { where } \mathrm{X} \text { is the mean expected loss, that is, the } \\
\text { mean expected returns of the fund above the VaR }\end{array}$ \\
\hline UD & $\begin{array}{l}\text { Deviation in the return on the investments }\left(\mathrm{r}_{\mathrm{t}}\right) \text { in } \\
\text { relation to a target return }\left(\mathrm{I}_{\mathrm{t}}\right) \text {. }\end{array}$ & $\begin{array}{c}\mathrm{UD}=\mathrm{r}_{\mathrm{t}}-\mathrm{I}_{\mathrm{t}}=\mathrm{r}_{\mathrm{t}}-\left\{\left[(1+\mathrm{i})\left(1+\mathrm{t}_{\mathrm{t}}\right)\right]-1\right\}, \\
\text { where } \mathrm{i} \text { is the financial discount rate of the actuarial } \\
\text { goal and } \pi_{\mathrm{t}} \text { is the inflation rate indexed to the } \\
\text { actuarial goal }\end{array}$ \\
\hline
\end{tabular}

$U D=$ unplanned divergence; $A R=$ appraisal ratio; $M^{2}=$ Modigliani and Modigliani ratio; $V a R=$ value-at-risk .

Source: Elaborated by the authors.

\section{METHODOLOGY}

\subsection{Sample Delimitation and Data Collection}

To fulfill the proposed objective, we chose investment funds, including those that invest in investment fund quotas, in which pension funds can allocate their resources, that is, open Brazilian funds meant for qualified and professional investors, listed on the Economatica platform. Of these, we chose those that follow the guidelines of CMN Resolution n. 4,661/2018 and excluded exclusive investment funds and those meant for exclusive investors.

The investment funds identified were segregated by investment segment, as classified by ANBIMA. The funds classified in the structured and foreign assets segments do not compose the sample of this study as they have low representativeness in the consolidated portfolios of pension funds (Abrapp, 2019). So, fixed income and stock funds were evaluated, as according to Table 2 . 
Table 2

Brazilian Association of Financial and Capital Market Entities (ANBIMA) classification of the funds analyzed in this study

\begin{tabular}{ll}
\hline Fixed income segment & ANBIMA classification \\
\hline Fixed income pension & Stock segment \\
\hline High duration fixed income* & Dividend stocks \\
\hline Low duration fixed income* & Indexed stocks \\
\hline Free duration fixed income* & Active index stocks \\
\hline Average duration fixed income* & Free stocks \\
\hline Indexed fixed income & Sector stocks \\
\hline Simple fixed income & Small cap stocks \\
\hline & Sustainability/governance stocks \\
\hline & Value/growth stocks \\
\hline
\end{tabular}

* Including funds classified as free credit, investment grade, and sovereign.

Source: Elaborated by the authors according to data available on the Economatica platform.

To identify outliers and inconsistent data present in the samples of investment funds, descriptive statistics were compiled and analyzed separately, case by case, regarding the need to exclude the information from the database. The data were validated by consulting the website of the Brazilian Securities and Exchange Commission (CVM) and corrected when necessary.

Thus, the sample of investment funds used in this study contains 369,237 of which were active and 132 were canceled on the data collection date (10/14/2019).

The data were collected in monthly frequency and cover the period from January of 2010 to December of 2018. Data from 2019 were not considered due to the lack of information regarding the pension funds for that period, making it impossible to evaluate the effectiveness of adopting the proposed techniques.

\subsection{Data Analysis}

The investment funds were analyzed in 12 temporal windows of 42 months each, the first 36 of which were used to estimate their performance and chose the best five, with the following six months being used to verify the effectiveness of the techniques adopted. For this, we only considered the funds with complete information in each temporal window and portfolio rebalancing every six months.

Within the context of pension funds, the fiscal council should issue, at least biannually, reports of internal controls that include conclusions about the adherence of the management of their guarantee resources to the current rules. For that reason, the portfolios built using the proposed techniques are rebalanced biannually.

Due to the specificities of each type of fund, the performance evaluation techniques were adopted according to their segment: (i) for funds classified in the fixed income segment, we adopted the Sharpe ratio, the alpha measured by a multifactor model, the efficiency of DEA, and the combinations of these techniques; (ii) for funds classified in the stock segment, we adopted the Sharpe ratio, the alpha from the asset pricing model proposed by Carhart, the efficiency of DEA, and the combinations of these techniques.

For the fixed income funds, the regression model equates to a multifactor model that considers reference indicators of the fixed income market. For the stock funds, the model equates to the one proposed by Carhart (1997), considering the Brazilian factors made available by the Center for Financial Economic Research of the School of Economics, Business, and Accounting of the University of São Paulo (NEFIN FEA-USP).

With relation to the risk-free asset adopted, according to Copeland et al. (1995), this should have an approximately null correlation with the market. Therefore, for the fixed income funds, the Brazilian Interbank Deposit Certificate (CDI) was adopted, which presents an insignificant correlation with the market and which presents negligible standard deviations (Piccoli et al., 2014), as well as being the index most adopted in the Brazilian literature as a proxy for the risk-free asset. For the stock ones, in turn, the DI-swap was adopted, as well as the NEFIN FEA-USP, calculated based on 30-day contracts. 
In all of the analyses, the indicators are adjusted by the maximum administration fee of the investment funds. For the funds in which the database did not present administration fee values, the mean rate of the other funds was adopted, as done by Oreng et al. (2017).

The results obtained through the different techniques were compared with each other and the effectiveness of each one was evaluated by comparing the returns obtained in the following period of the analysis with the mean actuarial goal of the benefits plans in the respective period, using the UD. With this, it is possible to identify the techniques that best reflect the performance of the investment funds in which the pension funds can allocate their resources, in terms of risks, returns, and costs.

Therefore, this study is of a descriptive qualitative nature and suggests the use of the statistical method based on secondary data. The data analysis was carried out in the R software, with the help of Excel.

\subsubsection{Sharpe ratio}

The Sharpe ratio was calculated in the performance evaluation period using the equation below, both for fixed income and for stock funds:

$$
\mathrm{SR}=\frac{\left.\overline{\mathrm{R}}_{\mathrm{i}}-\overline{\mathrm{R}}_{\mathrm{f}}-\mathrm{Adm}_{\mathrm{i}}\right)}{\sigma_{\mathrm{i}}}
$$

where $\bar{R}_{i}$ is the average return of the fund, $\bar{R}_{f}$ is the average return of the risk-free asset, $\mathrm{Adm}_{\mathrm{i}}$ is the maximum administration fee of the fund or the average fee, and $\sigma_{i}$ is the volatility of the fund's returns.

\subsubsection{Regression model alpha}

Fixed effects models were estimated with the aim of obtaining a Jensen's alpha for each fund and to be able to classify them according to their ability to generate return for investors. For this, balanced panels were considered and, therefore, funds that did not present complete information in each analysis period were excluded from the calculation.

For the fixed income funds, the references indexes of the segment were adopted as factors, in accordance with Oreng et al. (2017). Thus, the ANBIMA market indexes (IMA) (IMA-B, IMA-C, and IRF-M, except the IMA-S, which has a high correlation with the CDI) were considered to explain the returns of the fixed income funds. In addition, we also considered the ANBIMA debentures index (IDA), adopted as a reference for private securities, and the Bovespa index (Ibovespa), with the aim of trying to identify any relationship between the performance of the fixed income funds, according to variations in the Ibovespa.

Non-linear terms of the reference indexes adopted were also introduced into the model, as done by Treynor and Mazuy (1966) and reproduced by Ayadi et al. (2018) and Oreng et al. (2017) in their analysis of fixed income funds. With this, it is possible to verify whether the managers of the fixed income funds have market timing ability: if the coefficients estimated for these non-linear variables are different from 0 , there will be indications that the manager presents that ability.

The unrestricted model estimated for each analysis period is shown in equation 2 :

$$
\begin{aligned}
& \mathrm{R}_{\mathrm{it}}-\left(\mathrm{CDI}_{\mathrm{t}}-\mathrm{Adm}_{\mathrm{i}}\right)=\alpha_{\mathrm{i}}+\beta_{1}\left(\mathrm{IMAB}_{\mathrm{t}}-\mathrm{CDI}_{\mathrm{t}}-\mathrm{Adm}_{\mathrm{i}}\right)+\beta_{2}\left(\mathrm{IMAC}_{\mathrm{t}}-\mathrm{CDI}_{\mathrm{t}}-\mathrm{Adm}_{\mathrm{i}}\right)+ \\
& \beta_{3}\left(\mathrm{IRFM}_{\mathrm{t}}-\mathrm{CDI}_{\mathrm{t}}-\mathrm{Adm}_{\mathrm{i}}\right)+\beta_{4}\left(\mathrm{IDA}_{\mathrm{t}}-\mathrm{CDI}_{\mathrm{t}}-\mathrm{Adm}_{\mathrm{i}}\right)+\beta_{5}\left(\mathrm{IBOV}_{\mathrm{t}}-\mathrm{CDI}_{\mathrm{t}}-\mathrm{Adm}_{\mathrm{i}}\right)+ \\
& \beta_{6}\left(\left(\mathrm{IMAB}_{\mathrm{t}}-\mathrm{CDI}_{\mathrm{t}}-\mathrm{Adm}_{\mathrm{i}}\right)^{2}\right)+\beta_{7}\left(\left(\mathrm{IMAC}_{\mathrm{t}}-\mathrm{CDI}_{\mathrm{t}}-\mathrm{Adm}_{\mathrm{i}}\right)^{2}\right)+\beta_{8}\left(\left(\mathrm{IRFM}_{\mathrm{t}}-\mathrm{CDI}_{\mathrm{t}}-\right.\right. \\
& \left.\left.\mathrm{Adm}_{\mathrm{i}}\right)^{2}\right)+\beta_{9}\left(\left(\mathrm{IDA}_{\mathrm{t}}-\mathrm{CDI}_{\mathrm{t}}-\operatorname{Adm}_{\mathrm{i}}\right)^{2}\right)+\beta_{10}\left(\left(\mathrm{IBOV}_{\mathrm{t}}-\mathrm{CDI}_{\mathrm{t}}-\mathrm{Adm}_{\mathrm{i}}\right)^{2}\right)+\varepsilon_{i t}
\end{aligned}
$$

where $R_{i t}$ is the return of the investment fund, $\operatorname{Adm}_{\mathrm{i}}$ is the maximum administration fee charged by the investment fund or the average fee, $\mathrm{CDI}_{t}$ is the Interbank Deposit Certificate, $\mathrm{IMAB}_{\mathrm{t}}$ is the IMA for securities indexed by the national comprehensive consumer prices index (IPCA), IMAC $\mathrm{I}_{\mathrm{t}}$ is the IMA for securities indexed by the general market prices index (IGP-M), IRFM ${ }_{t}$ is the IMA for prefixed securities, $I_{D A}$ is the IDA, and $I_{B O V}$ is the Ibovespa, all in month $t$.
However, in each model we only maintained the variables that were shown to be significant to explain the returns of the investment funds at a 5\% significance level. So, there are different restricted models for each 36-month temporal window.

For the stock funds, in turn, the model adopted was the one proposed by Carhart (1997), as according to equation 3 .

$$
\mathrm{R}_{\mathrm{it}}-\left(\mathrm{R}_{\mathrm{ft}}-\mathrm{Adm}_{\mathrm{i}}\right)=\alpha_{\mathrm{i}}+\beta_{\mathrm{i}}\left(\mathrm{R}_{\mathrm{Mt}}-\left(\mathrm{R}_{\mathrm{ft}}-\mathrm{Adm}_{\mathrm{i}}\right)+\mathrm{s}_{\mathrm{i}} \mathrm{SMB}_{\mathrm{t}}+\mathrm{h}_{\mathrm{i}} \mathrm{HML}_{\mathrm{t}}+\mathrm{m}_{\mathrm{i}} \mathrm{MIM}_{\mathrm{t}}+\varepsilon_{\mathrm{it}}\right.
$$


where $R_{i t}$ is the return of the investment fund, $R_{f t}$ is the return of the risk-free asset, in this case the DI-swap, $\operatorname{Adm}_{\mathrm{i}}$ is the maximum administration fee charged by the investment fund or the average fee, $\mathrm{R}_{\mathrm{Mt}}$ is the return on the market portfolio, in this case the Ibovespa, $\mathrm{SMB}_{\mathrm{t}}$ is the size factor measured by the return on the portfolio with purchased stocks with low market capitalization (small) and sold stocks with low market capitalization (large), $\mathrm{HML}_{\mathrm{t}}$ is the book-to-market factor measured by the return on a purchased portfolio of stocks with a high book-to-market ratio and of stocks with a low book-tomarket ratio, and $\mathrm{MIM}_{\mathrm{t}}$ is the momentum factor measured by the return on a portfolio with purchased stocks with high past returns and sold stocks with low past returns, all in month $t$.

The factors calculated by the NEFIN FEA-USP were also considered. The calculation criteria are presented in the available documentation (NEFIN, 2020).

To validate the regression models, pertinent statistical tests were carried out: (i) the F test, to choose between the unrestricted models (with all the suggested variables) and the restricted models (composed only of those significant at the $5 \%$ level) in the case of the fixed income funds; (ii) the Breush-Pagan test, to verify the homoscedasticity of the residuals, that is, the hypothesis that the variances of the residuals of the model are equal $\left(E\left(e_{i}^{2}\right)=0\right)$; (iii) the Wooldridge test, to verify the serial independence of the residuals, that is, the hypothesis that there is no serial correlation in the residuals. To address the serial correlation and heteroscedasticity problems, the significance tests of the coefficients of the models were conducted considering robust standard errors.

It warrants mentioning that tests were conducted considering individual models to estimate the alphas of each investment fund analyzed and the selections obtained did not show many divergences in relation to the results, considering the panel data.

\subsubsection{Efficiency of DEA}

The DEA models estimated were based on the inputs and outputs adopted in similar studies that evaluate investment fund performance (Bisso et al., 2016; Fonseca et al., 2018; Macedo et al., 2010; Melo \& Macedo, 2013; Rubio et al., 2018).

Thus, the following variables were adopted as inputs: (i) the standard deviation of monthly returns; (ii) the logarithm of average equity; (iii) the average number of quota holders; (iv) the time in operation; and (v) the maximum administration fee. The fund's equity was adopted as an estimator of the size of the fund and, due to its large size, its logarithm was adopted in the calculations. As outputs, the monthly returns of the funds were adopted.

Super-efficiency models with variable returns to scale and oriented toward the output were estimated. For this, the TFDEA (Technology Forecasting using Data Envelopment Analysis) package proposed by Shott and Lim (2015) was used in the R software. This package is no longer active in the $\mathrm{R}$ distribution network and its functions were consulted in the $\mathrm{R}$ archives (https:// cran.r-project.org/src/contrib/Archive/TFDEA/). We chose to adopt this package due to it being possible to make the correlation proposed by Cook et al. (2009) for the decision making units (DMUs) that presented an unviable solution. It was thus possible to obtain efficiency scores for all of the funds analyzed.

\subsection{Evaluation of the Effectiveness of the Investment Fund Selection Techniques}

Using the performance evaluation techniques presented for each specific investment segment, scores were attributed to the investment funds, classifying them from best to worst performance (funds with better performance received a score of 1). In the combinations of the techniques, their scores were added up so that the lowest result indicates the best performance. In each analysis, five investment funds were chosen that stood out.

The effectiveness evaluation of the techniques was carried out using the UD, adopted as a reference index for the mean actuarial goal of the benefits plans. The goal is defined by the composition between the mean actuarial interest rate adopted by the benefits plans and an indexer, in this case the national consumer prices index (INPC), adopted by more than $50 \%$ of benefits plans (Ministério da Economia, 2021).

Thus, returns higher than the actuarial goal in the same period indicate that the technique adopted was effective for achieving or exceeding the actuarial goal of the pension benefits plans and, therefore, suitable for use by the pension funds when choosing investment funds.

The analyses were carried out considering the mean actuarial goals by modality of plan: defined benefit, variable contribution, and defined contribution. However, no relevant variations in the results were observed and, for that reason, only the results without segregation by modality are presented. 


\section{RESULTS ANALYSIS}

\subsection{Results for the Investment Fund Selection Techniques}

\subsubsection{Fixed Income}

It was verified that, over time, the returns obtained by the fixed income investment funds using the various techniques analyzed were more volatile in 2013 and as of 2017, approximately, coinciding with the period in which the basic interest rates of the economy were lower, as demonstrated by ANBIMA (2018). In the period from 2014 to 2016, when the Selic rose from $11 \%$ p.a. to $14.25 \%$, the highest value recorded in the last 15 years, the monthly returns of the fixed income funds were less volatile, recording values between 0 and $2 \%$ a month.

One hypothesis for the high volatility of the returns in the periods in which the basic interest rate of the economy was lower could be the reallocation of the portfolios of the investment funds into alterative assets, to try to obtain returns that meet their reference index; and in the moments of a rising basic interest rate in the economy, the migration to government-linked assets, which would provide high returns with approximately zero risk. However, a specific analysis is needed regarding the veracity of this hypothesis.

In Table 3, it is verified that adopting the Sharpe ratio to choose fixed income funds is a technique that presents the best performance measures, the highest average returns, and the lowest risk measured by the standard deviation. This technique resulted in the highest Sharpe ratio, Jensen's alpha, Modigliani and Modigliani ratio $\left(\mathrm{M}^{2}\right)$, Sortino ratio, and AR measures, as well as presenting the lowest systemic beta and, therefore, lower risk in relation to market variations. Both the historical and parametric value-at-risk (VaR) were positive, indicating that the potential loss of the investment would not really be a loss, but lower return. The conditional VaR, in turn, was negative, but it indicates a potential loss of only $0.56 \%$ p.m.

Table 3

Performance analysis of the fixed income fund selection techniques for the monthly returns obtained in the period from January of 2013 to December of 2018

\begin{tabular}{|c|c|c|c|c|c|c|c|}
\hline \multirow[b]{2}{*}{ Performance indicators } & \multicolumn{7}{|c|}{ Fixed income fund selection techniques } \\
\hline & SR & ALPHA & DEA & SR_ALPHA & SR_DEA & ALPHA_DEA & $\begin{array}{c}\text { SR_ALPHA_ } \\
\text { DEA }\end{array}$ \\
\hline Average return $(\%)$ & 0.95 & 0.68 & 0.81 & 0.83 & 0.86 & 0.71 & 0.75 \\
\hline $\begin{array}{l}\text { Standard deviation of } \\
\text { returns }(\%)\end{array}$ & 0.46 & 1.26 & 0.61 & 0.91 & 0.51 & 1.00 & 0.81 \\
\hline Sharpe ratio & 0.2659 & -0.1163 & -0.0300 & 0.0052 & 0.0715 & -0.1125 & -0.0705 \\
\hline Jensen's alpha & 0.0012 & -0.0014 & -0.0001 & 0.0001 & 0.0004 & -0.0010 & -0.0006 \\
\hline$M^{2}$ & 0.0243 & 0.0012 & 0.0064 & 0.0086 & 0.0126 & 0.0015 & 0.0040 \\
\hline Sortino ratio & 0.3692 & -0.1360 & -0.0402 & 0.0066 & 0.1063 & -0.1321 & -0.0840 \\
\hline $\mathrm{AR}$ & 65.0281 & -10.1152 & -4.1281 & 2.0304 & 18.4684 & -13.0827 & -17.9058 \\
\hline Systemic beta & 0.0219 & 0.0842 & 0.0370 & 0.0651 & 0.0324 & 0.0771 & 0.0606 \\
\hline Historical VaR 95\% & 0.0054 & -0.0297 & -0.0057 & -0.0114 & -0.0032 & -0.0169 & -0.0163 \\
\hline Parametric VaR 95\% & 0.0020 & -0.0140 & -0.0020 & -0.0066 & 0.0002 & -0.0093 & -0.0078 \\
\hline Conditional VaR 95\% & -0.0056 & -0.0299 & -0.0123 & -0.0234 & -0.0055 & -0.0215 & -0.0123 \\
\hline
\end{tabular}

ALPHA = multifactor model alpha; ALPHA_DEA = combination of the multifactor model alpha and data envelopment analysis $(D E A) ; S R=$ Sharpe ratio; $S R \_A L P H A=$ combination of the Sharpe ratio and the multifactor model alpha; SR_ALPHA_DEA = combination of the Sharpe ratio and the multifactor model alpha and DEA; SR_DEA = combination of the Sharpe ratio and DEA; $A R=$ appraisal ratio; $M^{2}=$ Modigliani and Modigliani ratio; $V a R=$ value-at-risk .

Source: Elaborated by the authors.

As with the adoption of the Sharpe ratio for choosing funds, the combination of this with DEA resulted in good performance measures.

In contrast, adopting the multifactor model alpha resulted in the worst performance measures in almost all of the indicators, except the AR, in which adopting the combination of the three techniques would result in the worst measure.

Figure 1 presents the mean and standard deviation descriptive statistics of the series of returns. It is verified 
that, as previously reported, adopting the Sharpe ratio results in the highest average return and the lowest risk. The worst technique is the multifactor model alpha, presenting the highest risk and the lowest return. For the fixed income funds, it is observed that the higher the risk observed between the returns obtained with each one of the techniques adopted, the lower the average return on the portfolio.

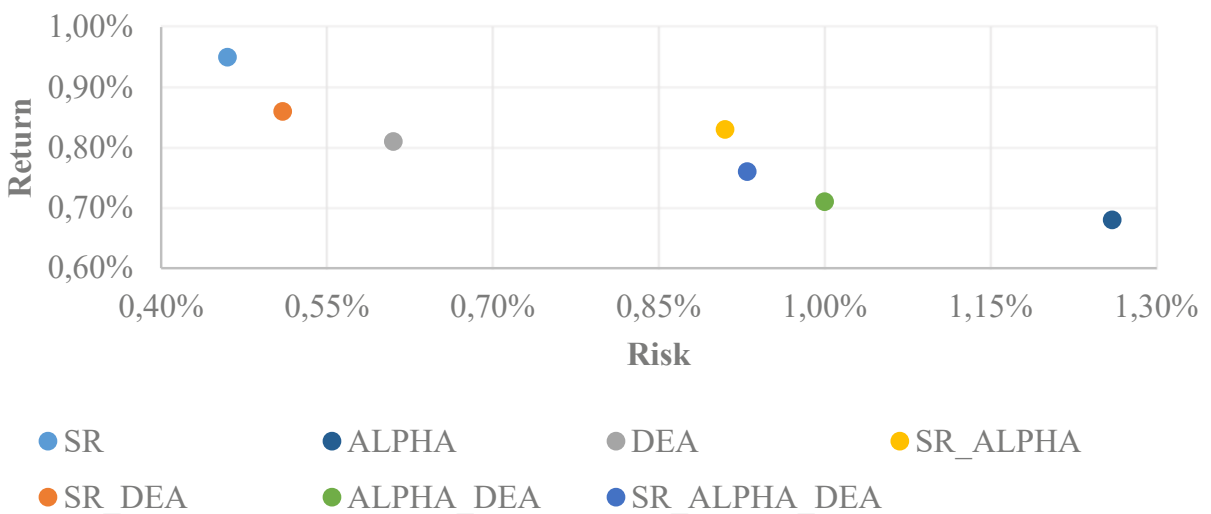

Figure 1 Risk and return relationship of the fixed income funds for each technique $A P L H A=$ multifactor model alpha; ALPHA_DEA = combination of the multifactor model alpha and data envelopment analysis $(D E A) ; S R=$ Sharpe ratio; $S R \_A L P H A=$ combination of the Sharpe ratio and the multifactor model alpha; $S R \_A L P H A \_D E A=$ combination of the Sharpe ratio and the multifactor model alpha and DEA; SR_DEA = combination of the Sharpe ratio and DEA.

Source: Elaborated by the authors.

\subsubsection{Stock investments}

For the stock funds, it was verified that, over time, the returns obtained using the various techniques presented values varying between -10 and $5 \%$ a month in 2013 , from -10 to $10 \%$ in the period from 2014 to 2018 , and from -15 to $15 \%$ a month in 2018 ; that is, a small increase is observed in the maximum and minimum values of the returns of the stock funds over the years.
Table 4 presents the performance measures calculated for the techniques adopted. It is verified that adopting the Sharpe ratio for choosing the stock funds is the technique that results in the highest average monthly return $(0.94 \%)$ and, despite not presenting the lowest volatility $(4.60 \%)$, it presents the highest number of performance measures with the best evaluation. The technique only did not excel when the Jensen's alpha and the parametric and conditional VaR were evaluated.

Table 4

Performance analysis of the stock fund selection techniques for the monthly returns obtained in the period from January of 2013 to December of 2018

\begin{tabular}{|c|c|c|c|c|c|c|c|}
\hline \multirow{2}{*}{ Performance indicators } & \multicolumn{7}{|c|}{ Stock fund selection techniques } \\
\hline & SR & ALPHA & DEA & SR_ALPHA & SR_DEA & ALPHA_DEA & SR_ALPHA_DEA \\
\hline Average return $(\%)$ & 0.94 & 0.81 & 0.69 & 0.82 & 0.69 & 0.73 & 0.80 \\
\hline Standard deviation of returns $(\%)$ & 4.60 & 4.85 & 4.38 & 4.76 & 4.15 & 4.25 & 4.28 \\
\hline Sharpe ratio & 0.0252 & -0.0035 & -0.0316 & -0.0006 & -0.0318 & -0.0219 & -0.0063 \\
\hline Jensen's alpha & 0.0021 & 0.0007 & -0.0005 & 0.0009 & -0.0005 & -0.0001 & 0.0006 \\
\hline$M^{2}$ & 0.0098 & 0.0081 & 0.0064 & 0.0082 & 0.0063 & 0.0069 & 0.0079 \\
\hline Sortino ratio & 0.0358 & -0.0049 & -0.0419 & -0.0008 & -0.0430 & -0.0299 & -0.0087 \\
\hline $\mathrm{AR}$ & 3.8161 & 1.0963 & -2.2490 & 1.4169 & -1.6095 & -0.2039 & 1.5186 \\
\hline Systemic beta & 0.6555 & 0.6752 & 0.6843 & 0.6683 & 0.6264 & 0.6325 & 0.6279 \\
\hline Historical VaR 95\% & -0.0674 & -0.0697 & -0.0737 & -0.0697 & -0.0702 & -0.0755 & -0.0736 \\
\hline Parametric VaR 95\% & -0.0663 & -0.0717 & -0.0651 & -0.0700 & -0.0614 & -0.0626 & -0.0624 \\
\hline Conditional VaR 95\% & -0.0965 & -0.1103 & -0.0914 & -0.1111 & -0.0818 & -0.0839 & -0.0880 \\
\hline
\end{tabular}

ALPHA = multifactor model alpha; ALPHA_DEA = combination of the multifactor model alpha and data envelopment analysis $(D E A) ; S R=$ Sharpe ratio; $S R \_A L P H A=$ combination of the Sharpe ratio and the multifactor model alpha; $S R \_A L P H A \_D E A=$ combination of the Sharpe ratio and the multifactor model alpha and DEA;SR_DEA = combination of the Sharpe ratio and DEA; $A R=$ appraisal ratio; $M^{2}=$ Modigliani and Modigliani ratio; $V a R=$ value-at-risk .

Source: Elaborated by the authors. 
The highest Jensen's alpha was observed when DEA was adopted for choosing the portfolios, and the parametric and conditional VaR excelled when a combination of the Sharpe ratio and DEA were adopted for choosing the portfolios.

Adopting the alpha estimated by the Carhart (1997) model or a combination of the Sharpe ratio and the alpha would also result in good performance measures, except for the parametric and conditional VaR, which presented the worst measures compared to the other techniques.

Figure 2 presents mean and standard deviation (risk) statistics for each one of the series of monthly returns. It is verified that, as previously reported, adopting the Sharpe ratio resulted in the highest return on the investment, despite not presenting the lowest risk. The technique that resulted in the lowest risk was the combination of the Sharpe ratio and DEA. However, this technique presented the second lowest return, the lowest being observed with the adoption of DEA. Thus, in contrast with what Oliveira and Pinheiro (2012) observed, adopting only DEA for choosing investment funds would not lead to extraordinary results.

The results presented are also consistent with what Fonseca et al. (2018) observed, who, for equity investment funds, found that adopting the Carhart (1997) model generates a better performance evaluation of the fund than when DEA scores are adopted.

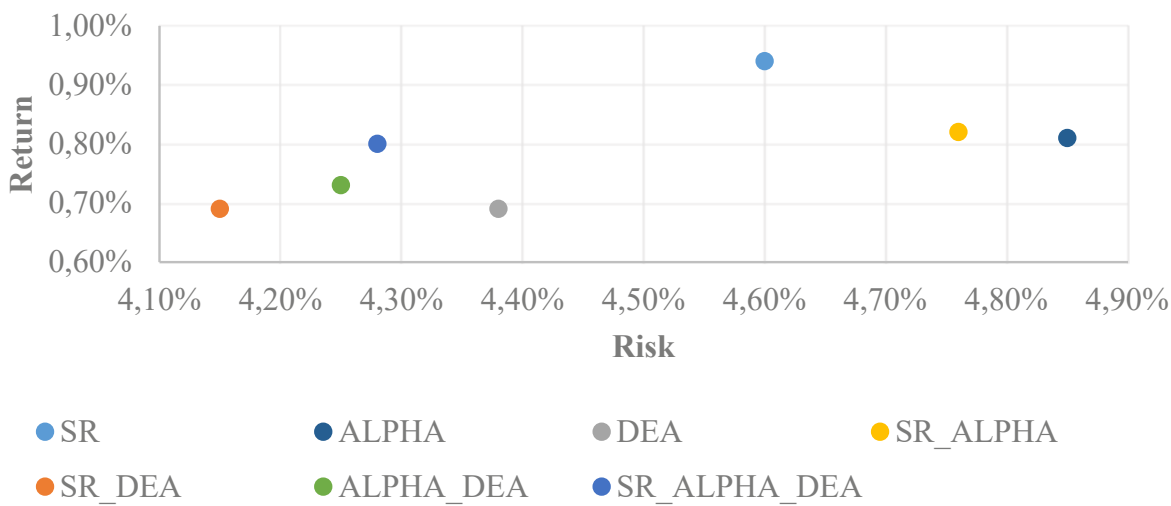

Figure 2 Risk and return relationship of the stock funds for each technique

APLHA = multifactor model alpha; ALPHA_DEA = combination of the multifactor model alpha and data envelopment analysis $(D E A) ; S R=$ Sharpe ratio; $S R \_A L P H A=$ combination of the Sharpe ratio and the multifactor model alpha; $S R \_A L P H A \_D E A=$ combination of the Sharpe ratio and the multifactor model alpha and DEA; SR_DEA = combination of the Sharpe ratio and DEA.

Source: Elaborated by the authors.

Unlike what was observed for the fixed income funds, for the stock funds higher return is observed when the portfolio risk is greater.

\subsection{Evaluation of the Effectiveness of the Techniques}

\subsubsection{Fixed income}

Table 5 presents some descriptive statistics for the monthly UDs of the fixed income funds. It is observed that adopting the Sharpe ratio for choosing the portfolio of funds resulted in a higher number of positive UDs (46), followed by a combination of the Sharpe ratio and DEA (43). Adopting DEA and a combination of the three techniques would result in the lowest number of positive UDs (approximately half).

Table 5

Descriptive statistics of the monthly unplanned divergences (UDs) of the fixed income funds by technique

\begin{tabular}{lccccccc}
\hline Statistics & SR & ALPHA & DEA & SR_ALPHA & SR_DEA & ALPHA_DEA & $\begin{array}{c}\text { SR_ALPHA_ } \\
\text { DEA }\end{array}$ \\
\hline Positive UDs & 46 & 40 & 37 & 43 & 41 & 38 & 37 \\
\hline Negative UDs & 26 & 32 & 35 & 29 & 31 & 34 & -0.17 \\
\hline Mean (\%) & 0.06 & -0.21 & -0.08 & -0.06 & -0.02 & -0.08 \\
\hline Standard deviation (\%) & 0.51 & 1.27 & 0.65 & 0.92 & 0.55 & 1.01 & 0.65 \\
\hline
\end{tabular}

ALPHA = multifactor model alpha; ALPHA_DEA = combination of the multifactor model alpha and data envelopment analysis $(D E A) ; S R=$ Sharpe ratio; SR_ALPHA = combination of the Sharpe ratio and the multifactor model alpha; SR_ALPHA_DEA = combination of the Sharpe ratio and the multifactor model alpha and DEA; SR_DEA = combination of the Sharpe ratio and DEA.

Source: Elaborated by the authors. 
Considering the adoption of each one of the techniques for the whole analysis period with biannual portfolio rebalancing, the cumulative returns and respective UDs are presented in Table 6 . It is verified that, in the long run, the only technique that resulted in a positive UD was the Sharpe ratio, with a return $8.38 \%$ above the mean actuarial goal of the benefits plans.

Table 6

Unplanned divergences (UDs) calculated considering the whole analysis period by technique

\begin{tabular}{lccccccc}
\hline Year & SR & ALPHA & DEA & SR_ALPHA & SR_DEA & ALPHA_DEA & SR_ALPHA_DEA \\
\hline Return $(\%)$ & 97.15 & 62.08 & 78.63 & 81.12 & 85.75 & 66.56 & 78.63 \\
\hline UD $(\%)$ & 8.38 & -26.69 & -10.13 & -7.65 & -3.02 & -22.21 & -10.13 \\
\hline
\end{tabular}

ALPHA = multifactor model alpha; ALPHA_DEA = combination of the multifactor model alpha and data envelopment analysis $(D E A) ; S R=$ Sharpe ratio; $S R \_A L P H A=$ combination of the Sharpe ratio and the multifactor model alpha; $S R \_A L P H A \_D E A=$ combination of the Sharpe ratio and the multifactor model alpha and DEA; SR_DEA = combination of the Sharpe ratio and DEA.

Source: Elaborated by the authors.

The second highest return was recorded adopting the combination of the Sharpe ratio and DEA, with a UD of $-3.02 \%$. On the other hand, the technique that resulted in the worst performance was the adoption of the multifactor model alpha, accumulating a return of only $62.08 \%$ and UD of $-26.69 \%$.

\subsubsection{Stock investments}

Table 7 presents some descriptive statistics for the monthly UDs of the stock funds. It is observed that adopting the Sharpe ratio or the Carhart model alpha or a combination of these two techniques would result in the highest number of positive UDs in the period analyzed.
However, this only means half of the monthly returns. The other techniques would result in negative UDs with a greater frequency than positive UDs. However, the first technique (Sharpe ratio) presented a mean UD of $0.06 \%$, the only positive mean among all of the techniques analyzed.

Table 7

Descriptive statistics of the monthly unplanned divergences (UDs) of the stock funds by technique

\begin{tabular}{|c|c|c|c|c|c|c|c|}
\hline Statistics & SR & ALPHA & DEA & SR_ALPHA & SR_DEA & ALPHA_DEA & $\begin{array}{c}\text { SR_ALPHA } \\
\text { DEA }\end{array}$ \\
\hline Positive UDs & 36 & 36 & 34 & 36 & 33 & 35 & 34 \\
\hline Negative UDs & 36 & 36 & 38 & 36 & 39 & 37 & 38 \\
\hline Mean (\%) & 0.06 & -0.08 & -0.20 & -0.06 & -0.19 & -0.15 & -0.09 \\
\hline $\begin{array}{l}\text { Standard } \\
\text { deviation (\%) }\end{array}$ & 4.71 & 4.95 & 4.48 & 4.86 & 4.25 & 4.35 & $4.38 \%$ \\
\hline
\end{tabular}

ALPHA = multifactor model alpha; ALPHA_DEA = combination of the multifactor model alpha and data envelopment analysis $(D E A) ; S R=$ Sharpe ratio; $S R \_A L P H A=$ combination of the Sharpe ratio and the multifactor model alpha; $S R \_A L P H A \_D E A=$ combination of the Sharpe ratio and the multifactor model alpha and DEA; SR_DEA = combination of the Sharpe ratio and DEA.

Source: Elaborated by the authors.

It is also observed that adopting DEA would result in a mean UD of $-0.20 \%$, indicating the worst performance compared to the mean actuarial goal of the benefits plans.
Considering the adoption of each one of the techniques for the whole analysis period with biannual portfolio rebalancing, the cumulative returns and respective UDs are presented in Table 8 . 
Table 8

Unplanned divergences (UDs) calculated considering the whole analysis period by technique

\begin{tabular}{lccccccc}
\hline Year & SR & \multirow{2}{*}{ ALPHA } & DEA & SR_ALPHA & SR_DEA & ALPHA_DEA & SR_ALPHA_ \\
DEA & & & & \\
\hline Return $(\%)$ & 82.56 & 67.79 & 53.40 & 69.49 & 55.08 & 58.94 & 66.79 \\
\hline UD $(\%)$ & -6.21 & -20.98 & -35.37 & -19.28 & -33.68 & -29.83 & -21.98 \\
\hline
\end{tabular}

ALPHA = multifactor model alpha; ALPHA_DEA = combination of the multifactor model alpha and data envelopment analysis $(D E A) ; S R=$ Sharpe ratio; $S R \_A L P H A=$ combination of the Sharpe ratio and the multifactor model alpha; SR_ALPHA_DEA = combination of the Sharpe ratio and the multifactor model alpha and DEA; SR_DEA = combination of the Sharpe ratio and DEA.

Source: Elaborated by the authors.

It is verified that, in the long run, all of the techniques would result in a negative UD. However, adopting the Sharpe ratio was the technique that presented the highest return $(82.56 \%)$ and, therefore, the least negative UD $(-6.21 \%)$. The worst performance would be obtained by adopting DEA for choosing the funds, with a cumulative return of $53.40 \%$ and UD of $-35.37 \%$.

Therefore, in the long run, despite the return obtained not being enough to reach or exceed the actuarial goal of the benefits plans, adopting the Sharpe ratio would result in the best result among the other techniques analyzed.

\section{CONCLUDING REMARKS}

Pension funds can strategically allocate their investments using techniques such as ALM and LDI, defining the portion to be applied in different, usually grouped, asset classes. The specific allocation is determined in a subsequent decision. This study sought to evaluate investment fund selection techniques from the perspective of pension funds. Therefore, all of the analyses were developed considering investment funds in which pension funds can allocate their resources, focusing on fixed income and stock ones, which together represent $66.1 \%$ of the consolidated portfolio of investments of pension funds (Abrapp, 2019).

Considering (i) the amount of significant resources moved by pension funds, (ii) the regulatory framework that determines the guidelines for applying their resources, (iii) the current economic environment of low interest rates, and (iv) the predominance of investments linked to government bonds in pension fund portfolios, the use of tools that enable investment fund performance to be evaluated is needed for strategic allocation and to take better advantage of market opportunities.

Thus, this study evaluates the effectiveness of some techniques usually adopted in the literature for this purpose, based on a calculation of the UD, considering the mean actuarial goal of the pension benefits plans as a reference index. So, effective investment fund selection techniques are ones that result in higher returns than the mean actuarial goals.
To choose the investment funds, three techniques and combinations of them were used: the Sharpe ratio, the multifactor model alpha, and DEA efficiency. For this, naive portfolios were simulated, composed of the five funds that stood out with each technique, and the series of returns generated in the period from 2013 to 2018 with each of these was analyzed, considering 36-month temporal windows.

It was verified that, from the perspective of pension funds, more robust techniques, which enable an infinity of variables to be considered, besides those related with the risks and returns of the funds, may not necessarily generate good results in the choice of investment. In the cases analyzed, both for fixed income funds and for stock funds, the simplest technique among those analyzed (the Sharpe ratio) was the one that resulted in the best returns.

For the fixed income funds, with this technique it would be possible to obtain higher returns than the mean actuarial goals of the benefits plans and, therefore, fulfill the investment objective. On the other hand, for the stock funds, which present greater volatility than fixed income ones, even though no portfolio exceeded the mean actuarial goal of the pension plans in the long run, adopting the Sharpe ratio resulted in the smallest loss. Each specific fund could weigh up these two results according to their investment policy and have a high probability of exceeding the goal. For example, considering the whole period analyzed and the fixed income and stock portfolios 
chosen using the Sharpe ratio, the manager could allocate up to $70 \%$ of the resources in stock funds where the actuarial goal of the period would be met. However, within this context, the greater the representativeness of fixed income, the better the results.

With relation to DEA, which is widespread in financial performance analyses, this is a technique in which the portfolio composed of funds indicated as being more efficient did not result in good performance, compared with the other portfolios elaborated using the other techniques. Unlike what was observed by Oliveira and Pinheiro (2012) for stock portfolios, DEA does not result in good performance when fixed income and stock funds are evaluated within the area of pension funds. In the same way as seen by Fonseca et al. (2018), adopting the Carhart model can generate a better evaluation of the fund's performance than DEA. However, as observed by Zakamouline (2010), the Sharpe ratio was shown to be appropriate for choosing investment funds and, for the specific case of pension funds, it is the indicator that presented the best investment effectiveness.

In general, the results found are consistent with the results obtained by Ornelas et al. (2012), obtaining different estimates for the different techniques used.

The results obtained in this study can be used by pension funds when choosing an investment fund to invest in, after carrying out the ALM and LDI studies. As these strategies do not provide guidance on which assets to invest in, from among the infinity of assets available in the market, adopting the Sharpe ratio to choose them could provide a higher probability of meeting the actuarial goal of the benefits plans.

However, other studies could be developed, considering, for example, instead of naïve portfolios, the optimization of a portfolio composed of funds that excel with each technique. Moreover, other segments could be evaluated, such as that of structured and foreign assets, despite these having low representativeness in the portfolios of pension funds, being alternative segments that can provide higher expected returns, better portfolio diversification, and, in some cases, better adaptation to the obligations of pension funds (Broeders et al., 2016).

Other types of assets that form part of the possibilities, such as investment in derivatives, holding funds such as private equity and venture capital funds, formally known in Brazil as FIPs (Fundos de Investimento em Participação) and FIEEs (Fundos de Investimento em Empresas Emergentes) (Lopes \& Furtado, 2006), could also be evaluated in future studies. Moreover, the health crisis period caused by coronavirus could be analyzed, which occurred in a period subsequent to the one analyzed in this study and which had a significant impact on the financial market. There are various tools that enable investment performance to be evaluated and, therefore, studies that adopt them could be developed in the future from the perspective of pension funds. Finally, integration between strategic allocation techniques (ALM and LDI, among others) and selection techniques, such as the ones studied here, could enable the incorporation of a higher number of restrictions on funds, facilitating more effective optimization of their own and outsourced investments.

One of the limitations of this study relates to the adoption of only seven techniques (three indicators) for choosing investment funds. Thus, to build the portfolios every semester, the other indicators presented in section 2.4 could also be the object of analysis. Moreover, the study could be reapplied considering different periodicities in the data series, reaffirming the results found for monthly series.

\section{REFERENCES}

Andonov, A., Bauer, R. M. M. J, \& Cremers, K. J. M. (2017). Pension fund asset allocation and liability discount rates. The Review of Financial Studies, 30(8), 2555-2595.

Associação Brasileira das Entidades dos Mercados Financeiro e de Capitais (Brazilian Association of Financial and Capital Market Entities). (2019). Indústria de fundos inicia o ano com captação líquida de $R$ \$10,3 bilhões. http://www.anbima. com.br/pt_br/informar/relatorios/fundos-de-investimento/ boletim-de-fundos-de-investimentos/industria-de-fundosinicia-o-ano-com-captacao-liquida-de-r-10-3-bilhoes-2CA08 A9A6872CD320168C7C0109040FC.htm
Associação Brasileira das Entidades dos Mercados Financeiro e de Capitais (Brazilian Association of Financial and Capital Market Entities). (2018). Multimercados e ações concentram recursos dos fundos de investimentos. http://www.anbima. com.br/pt_br/informar/relatorios/fundos-de-investimento/ boletim-de-fundos-de-investimentos/multimercados-e-acoesconcentram-recursos-dos-fundos-de-previdencia.htm

Associação Brasileira das Entidades Fechadas de Previdência Complementar (Brazilian Association of Closed Complementary Pension Entities). (2019). Consolidado estatístico - Dezembro 2019. https://www.abrapp. 
org.br/wp-content/uploads/2020/09/Consolidado-

Estati\%CC\%81stico_12_2019.pdf

Ayadi, M. A., \& Kryzanowski, L. (2011). Fixed-income fund performance: Role of luck and ability in tail membership. Journal of Empirical Finance, 18(3), 379-392.

Ayadi, M. A., Lazrak, S., Liao, Y., \& Welch, R. (2018). Performance of fixed-income mutual funds with regime-switching models. The Quarterly Review of Economics and Finance, 69, 217-231.

Bertucci, L. A., de Souza, F. H. R., \& Félix, L. F. F. (2006). Gerenciamento de risco de fundos de pensão no Brasil: alocação estratégica ou simples foco na meta atuarial? Revista Economia \& Gestão, 6(13), 1-17.

Bisso, C. S., Caldeira, J. F., Samanez, C. P., \& Telles, G. R. (2016). Produtividade e eficiência no mercado de fundos de investimento no Brasil: uma abordagem comparativa. Revista Brasileira de Finanças, 14(3), 323-352.

Blake, D., Rossi, A. G., Timmermann, A., Tonks, I., \& Wermers, R. (2013). Decentralized investment management: Evidence from the pension fund industry. The Journal of Finance, 68(3), 1133-1178.

Blake, D., Sarno, L., \& Zinna, G. (2017). The market for lemmings: The herding behavior of pension funds. Journal of Financial Markets, 36, 17-39.

Bogentoft, E., Romeijn, H. E., \& Uryasev, S. (2001). Asset/liability management for pension funds using CVaR constraints. The Journal of Risk Finance, 3(1), 57-71.

Bradley, D., Pantzalis, C., \& Yuan, X. (2016). The influence of political bias in state pension funds. Journal of Financial Economics, 119(1), 69-91.

Bragança, M. M. O., \& Pessoa, M. S. (2017). Análise de performance de fundos de investimento multimercado no Brasil. Revista Brasileira de Finanças, 15(1), 93-134.

Broeders, D. W. G. A, van Oord, A., \& Rijsbergen, D. R. (2016). Scale economies in pension fund investments: A dissection of investment costs across asset classes. Journal of International Money and Finance, 67, 147-171.

Carhart, M. M. (1997). On persistence in mutual fund performance. The Journal of Finance, 52(1), 57-82.

Ceretta, P., \& Costa, N., Jr. (2001). Avaliação e seleção de fundos de investimentos: um enfoque sobre múltiplos atributos. Revista de Administração Contemporânea, 5(1), 7-22.

Charnes, A., Cooper, W. W., \& Rhodes, E. (1978). Measuring the efficiency of decision making units. European Journal of Operational Research, 2(6), 429, 444.

Cook, W. D., Liang, L., Zha, Y., \& Zhu, J. (2009). A modified super-efficiency DEA model for infeasibility. Journal of the Operational Research Society, 60(2), 276-281.

Copeland, T., Koller, T., \& Murrin, J. (1995). Valuation (2a. ed.). Somerset.

Correia, J. J. A., Silva, W. B., \& Souza, F. C. (2018). Asset and liability management: modelo de otimização estocástica aplicável às entidades fechadas de previdência complementar brasileiras. In Anais do Congresso de Ciências Contábeis e Atuariais (20p.).
Dujim, P., \& Steins Bisschop, S. (2018). Short-termism of longterm investors? The investment behaviour of Dutch insurance companies and pension funds. Applied Economics, 50(31), 3376-3387.

Edelen, R. M., Ince, O. S., \& Kadlec, G. B. (2016). Institutional investors and stock return anomalies. Journal of Financial Economics, 119(3), 472-488.

Eling, M. (2008). Does the measure matter in the mutual fund industry? Financial Analysts Journal, 64(3), 54-66.

Fama, E. F., \& French, K. R. (1993). Common risk factors in the returns on stocks and bonds. Journal of Financial Economics, 33(1), 3-56.

Fonseca, N. F., Bressan, A. A., Iquiapaza, R. A., \& Guerra, J. P. (2007). Análise de desempenho recente de fundos de investimento no Brasil. Contabilidade Vista \& Revista, 18(1), 95-116.

Fonseca, S. E., Fernandes, A. R., Cunha, C. L., \& Iquiapaza, R. A. (2018). Fundos de investimento: performance aplicando modelo Carhart e análise envoltória de dados. Revista de Administração Contemporânea, 22(3), 355-379.

Guiotti, I. X. P., Costa, A. D. J. B., \& Botelho, D. R. (2020). Gestão de riscos em entidades fechadas de previdência complementar no Brasil: legislações, teorias e práticas de mercado. Revista Ciências Administrativas, 26(1), Artigo e90107.

Gutierrez, T., Pagnoncelli, B., Valladão, D., \& Cifuentes, A. (2019). Can asset allocation limits determine portfolio risk-return profiles in DC pension schemes? Insurance: Mathematics and Economics, 86, 134-144.

Hibiki, N. (2006). Multi-period stochastic optimization models for dynamic asset allocation. Journal of Banking \& Finance, 30(2), 365-390.

Ibbotson, R. G., \& Kaplan, P. D. (2000). Does asset allocation policy explain 40, 90, or 100 percent of performance? Financial Analysts Journal, 56(1), 26-33.

Jensen, M. C. (1968). The performance of mutual funds in the period 1945-1964. The Journal of Finance, 26(1), 389-416.

Lakonishok, J., Shleifer, A., Thaler, R., \& Vishny, R. (1991). Window dressing by pension fund managers. The American Economic Review, 81, 227-231.

Lopes, A. B., \& Furtado, C. V. (2006). Private equity na carteira de investimentos das entidades de previdência privada. Revista Contabilidade \& Finanças, 17(número especial), 108-126.

Macedo, M. A. D. S., Fontes, P. V. D. S., Cavalcante, G. T., \& Macedo, H. D. R. (2010). Análise do grau de atratividade de fundos de renda fixa: uma abordagem multicriterial da estrutura de oferta utilizando DEA. Contextus - Revista Contemporânea de Economia e Gestão, 8(1), 71-82.

Melo, R. A., \& Macedo, M. Á. da S. (2013). Análise multicriterial do desempenho de longo prazo das carteiras de ações de fundos de investimento multimercado macro no Brasil no período de 2005 a 2010. Revista Evidenciação Contábil \& Finanças, 1(2), 69-89.

Ministério da Economia. (2021). Hipóteses atuariais. https:// www.gov.br/economia/pt-br/orgaos/entidades-vinculadas/ 
autarquias/previc/acesso-a-informacao/dados-abertos/ hipoteses-atuariais/hipoteses-atuariais-por-plano-2018.xlsx/ view

Mitra, G., \& Medova, E. (2010). Asset and liability management/ liability-driven investment for pension funds. Journal of Asset Management, 11(2), 71-72.

Modigliani, F., \& Modigliani, L. (1997). Risk-adjusted performance. Journal of Portfolio Management, 23(2), 45.

Nevins, D. (2004). Goals-based investing. The Journal of Wealth Management, 6(4), 8-23.

Novy-Marx, R., \& Rauh, J. (2011). Public pension promises: How big are they and what are they worth? The Journal of Finance, 66(4), 1211-1249.

Núcleo de Pesquisa em Economia Financeira da Universidade de São Paulo. (2020). Risk factors. http://nefin.com.br/risk_ factors.html

Oliveira, A. D., Filomena, T. P., \& Righi, M. B. (2018). Performance comparison of scenario-generation methods applied to a stochastic optimization asset-liability management model. Pesquisa Operacional, 38(1), 53-72.

Oliveira, A. D., Filomena, T. P., Perlin, M. S., Lejeune, M., \& de Macedo, G. R. (2017). A multistage stochastic programming asset-liability management model: An application to the Brazilian pension fund industry. Optimization and Engineering, 18(2), 349-368.

Oliveira, A. E., \& Pinheiro, P. R. (2012). Analysis of the model DEA-CCR in the selection of investments of the pension funds entities. Proceedings of the Information Science and Industrial Applications (ISI), Cebu, Philippines, 29-31, 151-156.

Oreng, M. A. C., Eid, W., Jr., \& Yoshinaga, C. E. (2017). Performance of fixed income funds in Brazil: Market-timing and style analysis. Revista de Gestão, Finanças e Contabilidade, 7(3), 314-325.

Organisation for Economic Co-operation and Development. OECD Pension markets in focus, 2018. https://www. fiapinternacional.org/en/oecd-pension-markets-in-focus2018-oecd-october-2018/

Ornelas, J. R. H., Silva, A. F., Jr., \& Fernandes, J. L. B. (2012). Yes, the choice of performance measure does matter for ranking of us mutual funds. International Journal of Finance \& Economics, 17(1), 61-72.

Piccoli, P. G. R., Cruz, J. A. W., \& Citadin, M. W. (2014). Determinando a taxa livre de risco para a aplicação do CAPM no mercado brasileiro. REAVI - Revista Eletrônica do Alto do Vale do Itajaí, 3(4), 1-11.

Rauh, J. D. (2008). Risk shifting versus risk management: Investment policy in corporate pension plans. The Review of Financial Studies, 22(7), 2687-2733.

Resolution n. 4,661/2018. (2018). Discusses the guidelines for applying the guarantee resources of plans administered by closed complementary pension entities. https://www.in.gov. br/web/guest/materia/-/asset_publisher/Kujrw0TZC2Mb/ content/id/16299167/do1-2018-05-29-resolucao-n-4-661-de25-de-maio-de-2018-16299163

Rubio, J. F., Maroney, N., \& Hassan, M. K. (2018). Can efficiency of returns be considered as a pricing factor? Computational Economics, 52(1), 25-54.

Saad, N., \& Ribeiro, C. O. (2004). Modelos determinísticos de gestão de ativo/passivo: uma aplicação no Brasil. Revista Contabilidade \& Finanças, 15(34), 50-62.

Sharpe, W. F. (1966). Mutual fund performance. The Journal of Business, 39(1), 119-138.

Shott, T., \& Lim, D. J. (2015). TFDEA: Technology forecasting using $D E A$ (data envelopment analysis). $R$ package version 0.9.8.3. https://CRAN.R-project.org/package=TFDEA

Silva, S. A. L., Bressan, A. A., \& Ferreira, B. P. (2015). Avaliação da eficácia dos modelos de asset liability management e liability driven investment para um fundo de pensão brasileiro. In Anais do XXXIX Encontro da Associação Nacional de Pós-Graduação e Pesquisa em Administração (22p.).

Silva, S. E., Roma, C. M. S., \& Iquiapaza, R. A. (2020). Turnover da carteira e o desempenho de fundos de investimentos em ações no Brasil. Revista Contabilidade \& Finanças, 31(83), 332-347.

Sortino, F. A., \& van der Meer, R. (1991). Downside risk. Journal of Portfolio Management, 17(4) 27.

Treynor, J., \& Mazuy, K. (1966). Can mutual funds outguess the market? Harvard Business Review, 44(4), 131-136.

Varga, G. (2001). Índice de Sharpe e outros indicadores de performance aplicados a fundos de ações brasileiros. Revista de Administração Contemporânea, 5(3), 215-245.

Zakamouline, V. (2010). The choice of performance measure does influence the evaluation of hedge funds [Working Paper]. Social Science Research Network. http://dx.doi.org/10.2139/ ssrn. 1403246 